\title{
Application of Life Cycle Assessment to Lithium Ion Batteries in the Automotive Sector
}

\author{
Rosario Tolomeo ${ }^{\circledR}$, Giovanni De Feo *®D, Renata Adami ${ }^{\circledR}$ and Libero Sesti Osséo \\ Department of Industrial Engineering, University of Salerno, Via Giovanni Paolo II, 132, 84084 Fisciano (Sa), \\ Italy; rtolomeo@unisa.it (R.T.); radami@unisa.it (R.A.); lsestiosseo@unisa.it (L.S.O.) \\ * Correspondence: g.defeo@unisa.it; Tel.: +39-089-96-4113
}

Received: 28 April 2020; Accepted: 31 May 2020; Published: 5 June 2020

\begin{abstract}
This study is a critical review of the application of life cycle assessment (LCA) to lithium ion batteries in the automotive sector. The aim of this study is to identify the crucial points of the analysis and the results achieved until now in this field. In the first part of the study, a selection of papers is reviewed. In the second part of the study, a methodological approach to LCA is adopted to make clear the strengths and weaknesses of this analysis method. The lack of primary data is a crucial concern. Even if the cradle-to-grave approach is the most chosen system boundary, further scientific contribution to the life cycle inventory phase is necessary. It is likely that the more the electric vehicle becomes widespread, the more data will be accessible. Many authors have not specified the chemistry of the used batteries (5\% of the studies), the software tool used $(30 \%)$ or the functional unit used $(17 \%)$ and, consequently, their obtained results can be questionable. However, even with the aforementioned limitations, the performed review allows us to point out the potential of electric vehicles and lithium ion batteries to reduce the overall contribution of the transportation sector to GHG emissions.
\end{abstract}

Keywords: automotive industry; electric vehicles; LCA; lithium ion batteries; second life

\section{Introduction}

Advanced power storage devices are increasingly desirable for stationary and mobile applications. High energy and power density are required for the more recent mobile applications, to keep safety standards high. In contrast, older batteries characterized by long life and reliability are suitable for stationary applications [1]. Lithium ion cells are among the most suitable candidates for both these kinds of applications, thanks to their power and energy density as well as their low self-discharge rate [2]. They are essentially made of two electrodes, an electrolyte that closes the electrical circuit, assuring the ionic transport, a separator preventing the short-circuiting of the cell due to electrodes' contact, and two current collectors. The cathode, which is the positive electrode, is the only element that changes across the different lithium batteries' chemistry [3].

During the past decade, lithium ion cells have been widely used in the automotive sector as energy sources for electric vehicles (EV), hybrid electric vehicles (HEV) and plug-in hybrid electric vehicles (PHEV) [4]. Figure 1 shows the geography of lithium battery producers. The Asiatic area is predominant: China is the biggest producer of lithium ion cells and batteries; together with Japan and South Korea, it makes more than three-quarters of the entire world's production. Among all other countries, only the USA has significant production [5]. 


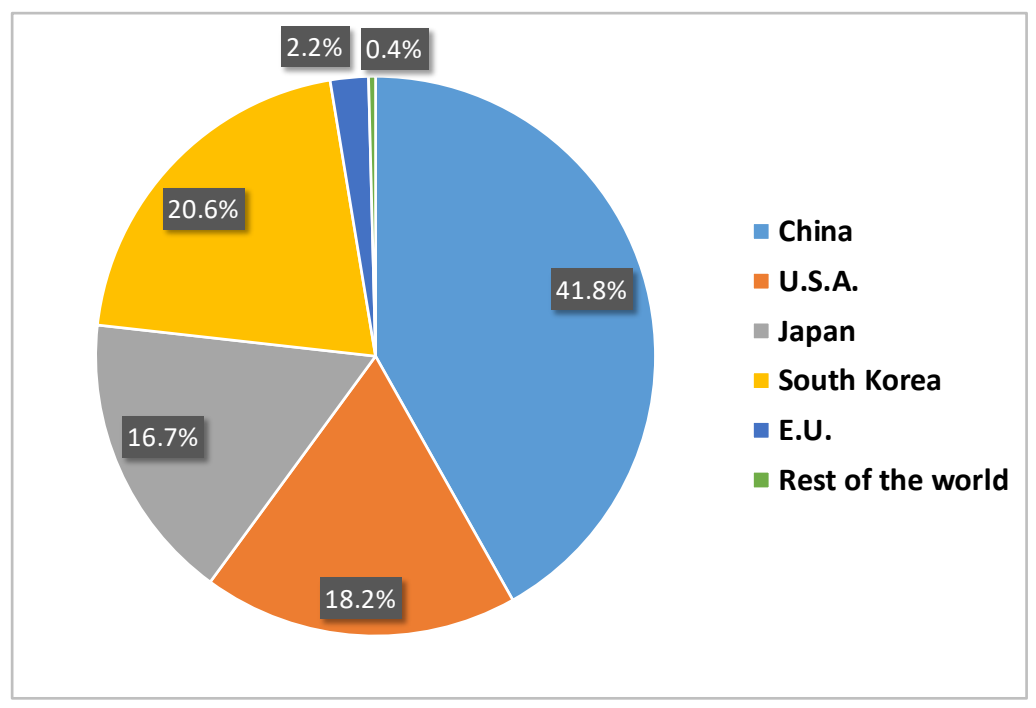

Figure 1. Distribution of lithium ion cell production in the world [5].

Total production of lithium ion batteries (LIBs) was $103 \mathrm{GWh}$ or 11,400 metric tons in the year 2017 , and in the future a quick increase is expected. The forecast annual demand for LIBs is $1300 \mathrm{GWh}$ (145,000 metric tons) in 2030 [6]. The annual demand for LIBs, and for raw materials as a consequence, is related to the market penetration of EVs, batteries' lifespan and recycling capacity.

The lifespan of LIBs is influenced by secondary reactions that lead to the degradation of their components and results in an increase of internal impedance and in a decrease of residual capacity $[7,8]$. The mechanisms causing the decrease of the overall performance of LIBs are known as "aging mechanisms". It is important to consider these mechanisms in order to improve the performance of the batteries and precisely check the health status of the cells (SOH) [9].

The lifespan of LIBs in automotive applications is estimated to be up to ten years [10]. At the end of life (EOL) of automotive applications, batteries are not suitable for mobility because they do not guarantee a sufficient autonomy and traction capacity. Nevertheless, they have sufficient residual capacity to stabilize an electricity grid in their so-called "second life" [11] or in energy storage systems (ESS) for residential, commercial or industrial applications [12]. The criteria to change from mobile to stationary use for lithium ion batteries at EOL are commonly agreed as:

- Residual capacity of the battery in the range of $60-80 \%$ with respect to the initial capacity [13];

- Doubling of internal impedance with respect to the initial capacity [14].

Extracting a second use from repurposed EV batteries may also assist EV owners in recovering some of the initial costs of the vehicle purchase [11]. After the end of the second life, it has been shown that the recycling of lithium ion batteries can be beneficial to the environment because it reduces first of all material discharge, and reduces greenhouse gas emissions (GHGs) as well as avoids the extraction of new raw materials. However, similarly to any other industrial process, it is impossible to recycle LIBs without causing environmental impacts with the recycling processes [15]. Therefore, the impact of recycling LIBs has to be evaluated.

The life cycle assessment (LCA) methodology can be used to evaluate the potential environmental impacts. The LCA method provides an overall view of the life cycle of products, processes or services during the entire life cycle (cradle-to-grave approach) or only some parts of it (cradle to gate, gate to grave, etc.). The use of a "cradle-to-gate" approach considers all energy transformation, material and components production and assembly, from resource extraction to the factory gate. A "cradle-to-grave" approach considers cradle-to-gate phases, adding use and disposal phases. The "well-to-wheel" approach is usually used for fuels. Inputs and outputs of an LCA study have to be referred to as a functional unit (F.U.), which is a measure of the function of the studied system. The International 
Standards Organization (ISO) provides all the necessary guidelines to perform an LCA in the ISO 14000 series [16,17]. A framework of the LCA phases is shown in Figure 2.

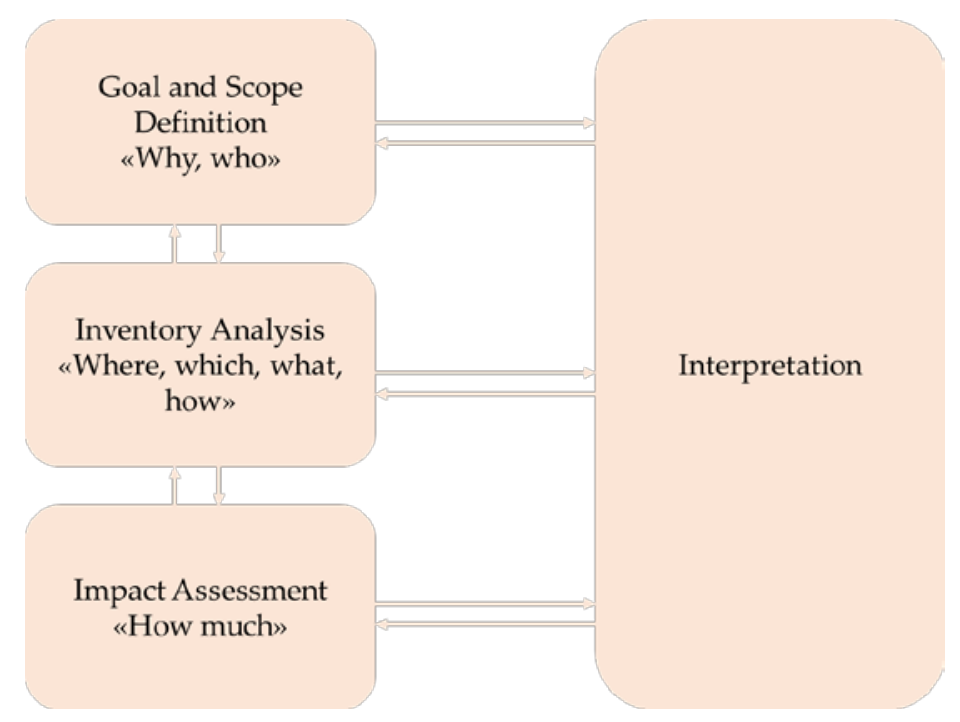

Figure 2. Life cycle assessment phases as described in ISO 14040.

LCA studies on LIBs are growing in interest, but they are still under development. In April 2020 , a total of 383,000 papers is available on LIBs, but only one out of a hundred is related to LCA or energetic and environmental analysis. In this review, fifty-nine papers and studies on the topic have been selected in literature. As a rule, papers without original and proven results have not been considered. As shown in Figure 3, among the reviewed studies, the number of publications has grown over the years.

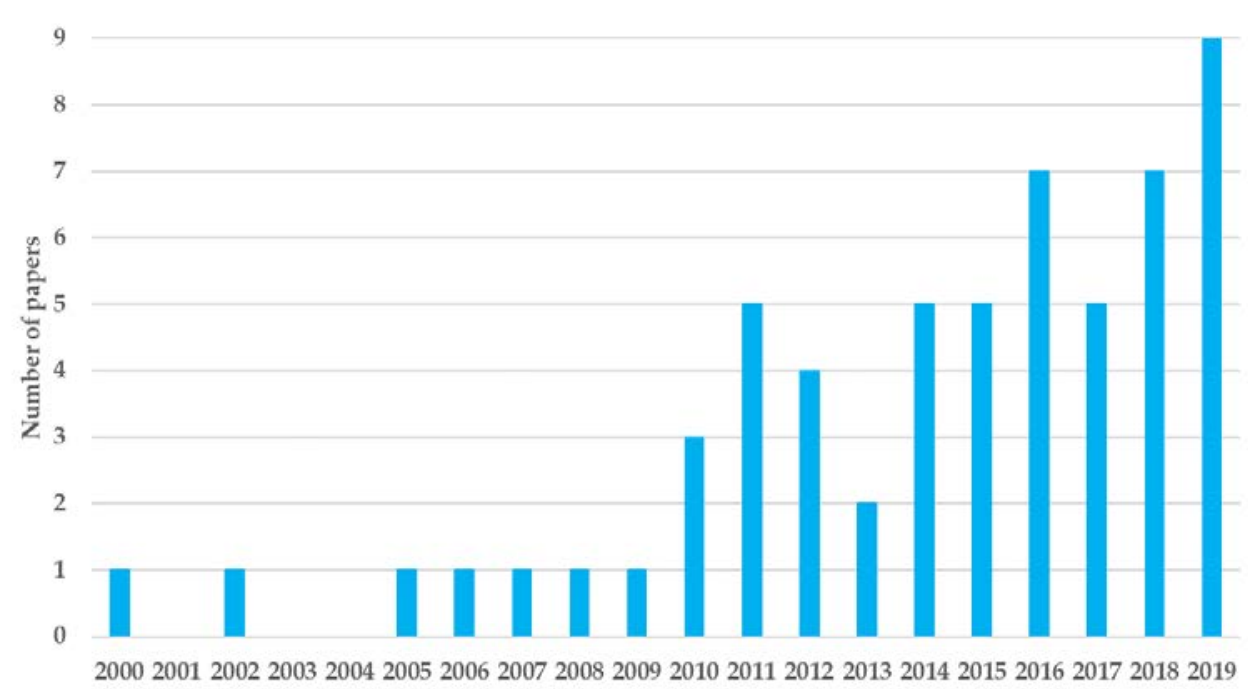

Figure 3. Distribution over year for the reviewed literature.

The research of papers has been conducted on the main available scientific databases (Scholar, Scopus, Science Direct, Web of Knowledge, etc.) using different key words such as LCA, life cycle assessment, electric vehicle, battery, lithium ion battery, hydrometallurgy, pyrometallurgy, recycling, second life, end of life, etc. as well as combining them with the 'and' boolean operator.

Specialized journals are the main sources for the reviewed literature. As shown in Figure 4, many contributions are from the Journal of Cleaner Production and Environmental Science E Technology. 


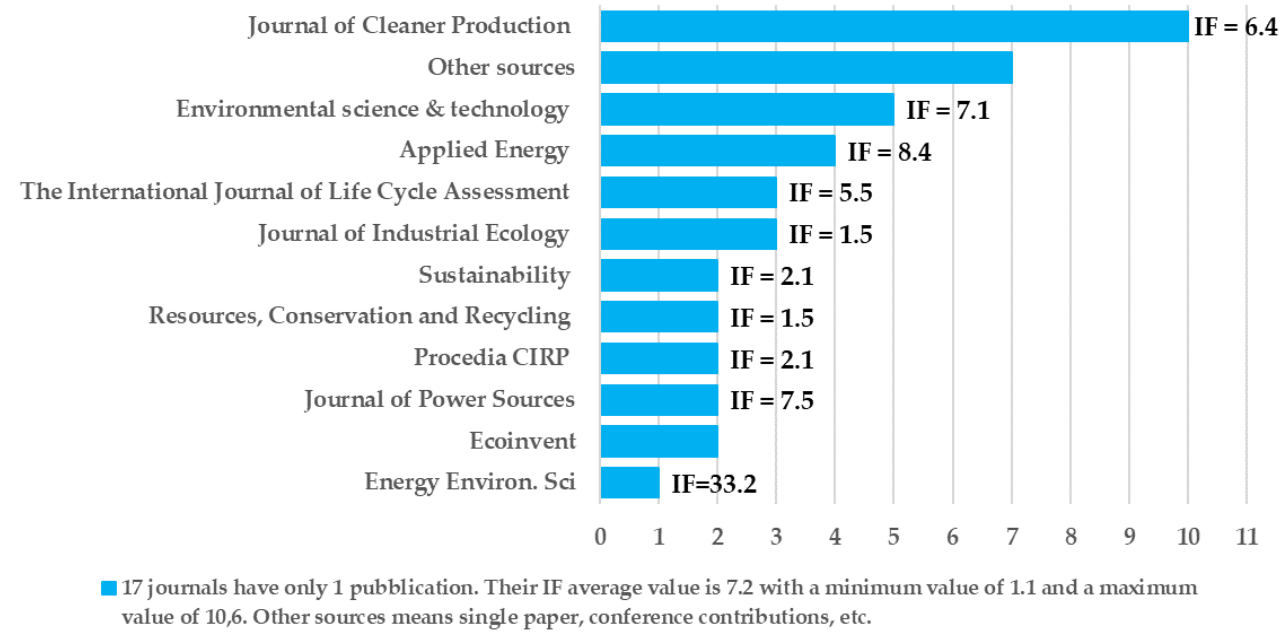

Figure 4. Number of publications per journal among the reviewed literature (IF = impact factor).

Among the selected studies, thirty-two are LCA papers on EV, twenty-three are LCA studies on LIBs and four are not related to LCA studies but to cost and energy analysis.

Identifying the main aim of the papers reviewed is important. In $51 \%$ of the studies, a cradle-to-grave approach was used; for example, Marques et al. [18] implemented a cradle-to-grave study in order to compare the environmental behavior of electric vehicles with different cathode's chemistries. In $25 \%$ of the studies, a well-to-wheel approach was used; Faria et al. [9], for example, analyzed the advantages of batteries repurposed for energy storage at home in cases of peak shaving and load shifting. Despite being similar, the cradle-to-grave approach focuses on the product, process or service considered, whereas the well-to-wheel approach mainly focuses on the fuel.

Table 1 shows the main characteristics of the studies considered in this review.

Table 1. Main characteristics of the studies considered in this review.

\begin{tabular}{|c|c|c|c|c|}
\hline LCA $^{\text {a }}$ Approach & Functional Unit (F.U.) & Main Topic & Location & References \\
\hline \multicolumn{5}{|c|}{ Battery } \\
\hline Cradle-to-cradle & $1 \mathrm{kWh}$ & $\begin{array}{l}\text { LCA analysis on recycling and } \\
\text { reuse of lead acid, LIBs }{ }^{b} \text { and } \\
\text { vanadium redox flow batteries }\end{array}$ & Germany & 2016 [19] \\
\hline \multirow{6}{*}{ Cradle-to-gate } & $1 \mathrm{~kg}$ of cathode & $\begin{array}{l}\text { Different impact assessment } \\
\text { methods comparison }\end{array}$ & - & 2019 [20] \\
\hline & $1 \mathrm{~kg}$ of raw material & $\begin{array}{l}\text { Real energy demand and } \\
\text { GHGs }^{\mathrm{c}} \text { emission comparison } \\
\text { to GREET }{ }^{\mathrm{d}}\end{array}$ & China & 2019 [21] \\
\hline & $1 \mathrm{kWh}$ & LCA on NMC ${ }^{\mathrm{e}}$ battery & United States & 2019 [15] \\
\hline & $100 \mathrm{~kg}$ of batteries & $\begin{array}{l}\text { Production environmental } \\
\text { impact of different batteries } \\
\text { (LIBs and non-LIBs) }\end{array}$ & United Kingdom & 2012 [22] \\
\hline & $1000 \mathrm{kWh}$ & $\begin{array}{l}\text { LCA comparison among LIBs, } \\
\text { NMHs and solar cells }\end{array}$ & China & 2016 [23] \\
\hline & $\begin{array}{l}\text { Local energy demand } \\
{[\mathrm{MWh}]}\end{array}$ & $\begin{array}{l}\text { Optimized consequential LCA } \\
\text { for ESS }{ }^{f} \text { application }\end{array}$ & France & 2019 [24] \\
\hline $\begin{array}{l}\text { Cradle-to-gate + } \\
\text { end-of-life }\end{array}$ & $17 \mathrm{kWh}$ & $\begin{array}{c}\text { LCA on innovative LIB } \\
\text { chemistry }\end{array}$ & - & 2018 [3] \\
\hline $\begin{array}{l}\text { Cradle-to-gate, } \\
\text { cradle-to-grave }\end{array}$ & 1 battery pack $(250 \mathrm{~kg})$ & LCA approach and EIO g-LCA & United Kingdom & 2019 [25] \\
\hline
\end{tabular}


Table 1. Cont.

\begin{tabular}{|c|c|c|c|c|}
\hline LCA $^{\text {a }}$ Approach & Functional Unit (F.U.) & Main Topic & Location & References \\
\hline \multirow{11}{*}{ Cradle-to-grave } & 1 battery & $\begin{array}{l}\text { Complete LCI for NCM } \\
\text { battery }\end{array}$ & - & 2014 [26] \\
\hline & 1 battery pack (346 kg) & $\begin{array}{l}\text { LCA on LithoRec project for } \\
\text { LIBs recycling }\end{array}$ & Germany & 2018 [27] \\
\hline & 1 battery pack (43.2 kWh) & $\begin{array}{l}\text { LCA on battery with silicon } \\
\text { nanowire anode }\end{array}$ & - & 2014 [28] \\
\hline & 1 battery pack (43.75 mAh) & LCA on SSBs manufacturing & Germany & 2016 [29] \\
\hline & \multirow{4}{*}{$1 \mathrm{kWh}$} & LCA on different battery types & - & $2015[30]$ \\
\hline & & $\begin{array}{c}\text { LCA on battery reused for ESS } \\
\text { application }\end{array}$ & Canada & 2015 [11] \\
\hline & & $\begin{array}{l}\text { LCA on new advanced } \\
\text { material for LIBs }\end{array}$ & European Union & $2011[31]$ \\
\hline & & $\begin{array}{l}\text { Environmental burdens of } \\
\text { used batteries }\end{array}$ & Japan & 2002 [32] \\
\hline & $1 \mathrm{MWh}$ & $\begin{array}{l}\text { LCA comparison between } \\
\text { LIBs and LMPs }\end{array}$ & Canada (Quebec) & 2017 [33] \\
\hline & $\begin{array}{l}50 \mathrm{~kW} \text { power / } 450 \mathrm{kWh} \\
\text { capacity }\end{array}$ & $\begin{array}{l}\text { Energy analysis on eight } \\
\text { battery technologies }\end{array}$ & - & $2005[34]$ \\
\hline & $\begin{array}{c}\text { Average yearly energy } \\
\text { balance }\end{array}$ & $\begin{array}{c}\text { LCA of repurposed EV } \\
\text { batteries in ESS applications }\end{array}$ & Netherlands & 2018 [12] \\
\hline $\begin{array}{c}\text { End-of-life } \\
\text { (recycling phase) }\end{array}$ & 1 metric ton of batteries & $\begin{array}{l}\text { LIBs recycling processes } \\
\text { investigation and LCA }\end{array}$ & Australia & 2016 [14] \\
\hline \multirow[t]{2}{*}{ Well-to-wheel } & - & $\begin{array}{c}\text { Different battery chemistries } \\
\text { assessment }\end{array}$ & European Union & 2012 [35] \\
\hline & $1 \mathrm{~km}$ & LCA study & Sweden & $2016[36]$ \\
\hline & & Vehicle & & \\
\hline \multirow{3}{*}{ Cradle-to-gate } & - & $\begin{array}{l}\text { Energy consumption and } \\
\text { GHGs emissions evaluation of } \\
\text { ICEVs }^{i} \text { and BEVs }{ }^{j} \text { production }\end{array}$ & China & 2017 [37] \\
\hline & $\begin{array}{c}100,000,150,000 \text { and } \\
200,000 \mathrm{~km}\end{array}$ & $\begin{array}{l}\text { Impact of driving patterns, } \\
\text { geographic locations and } \\
\text { heating/cooling use on energy } \\
\text { consumption of EV. LCA } \\
\text { approach. }\end{array}$ & $\begin{array}{l}\text { Germany, Brazil } \\
\text { and Spain }\end{array}$ & 2015 [38] \\
\hline & $150,000 \mathrm{~km}$ & LCA study on BEV and ICEV & European Union & 2018 [39] \\
\hline \multirow{7}{*}{ Cradle-to-grave } & \multirow{3}{*}{-} & $\begin{array}{l}\text { LCA on BEV, HEV and PHEV } \\
\text { with LMO }{ }^{\mathrm{k}} \text { batteries }\end{array}$ & United States & $2012[40]$ \\
\hline & & $\begin{array}{l}\text { LCA study for different LIB } \\
\text { chemistry in PHEV }{ }^{1}\end{array}$ & United States & $2011[41]$ \\
\hline & & $\begin{array}{l}\text { Energy use and GHGs } \\
\text { emission of vehicle }\end{array}$ & United States & 2010 [42] \\
\hline & \multirow{3}{*}{$1 \mathrm{~km}$} & $\begin{array}{l}\text { LCA on five different } \\
\text { powertrain scenarios }\end{array}$ & Brazil & 2018 [43] \\
\hline & & $\begin{array}{l}\text { LCA comparison between } \\
\text { ICEVs and BEVs }\end{array}$ & European Union & 2016 [44] \\
\hline & & $\begin{array}{l}\text { LCA on different EV types and } \\
\text { LIB chemistries }\end{array}$ & United States & 2016 [45] \\
\hline & $1 \mathrm{kWh}$ & $\begin{array}{l}\text { Different impact methods } \\
\text { sensitivity on electric } \\
\text { powertrains LCA }\end{array}$ & European Union & 2017 [46] \\
\hline
\end{tabular}


Table 1. Cont.

\begin{tabular}{|c|c|c|c|c|}
\hline LCA $^{\text {a }}$ Approach & Functional Unit (F.U.) & Main Topic & Location & References \\
\hline & 1 mile & $\begin{array}{l}\text { LCA analysis on different } \\
\text { advanced powertrains }\end{array}$ & United States & 2018 [5] \\
\hline & $100 \mathrm{~km}$ & $\begin{array}{l}\text { Carbon and water footprint } \\
\text { analysis }\end{array}$ & Czech & 2019 [47] \\
\hline & $120,000 \mathrm{~km}$ & $\begin{array}{l}\text { Batteries production impact } \\
\text { on EV life cycle }\end{array}$ & United States & 2015 [48] \\
\hline & $150,000 \mathrm{~km}$ & $\begin{array}{l}\text { LCA with present and future } \\
\text { energy mixes }\end{array}$ & $\begin{array}{l}\text { Czech and } \\
\text { Poland }\end{array}$ & 2018 [49] \\
\hline & $160,000 \mathrm{~km}$ & $\begin{array}{l}\text { LCA on electric vehicle and } \\
\text { LIBs second life scenarios }\end{array}$ & Canada & 2014 [10] \\
\hline & $200,000 \mathrm{~km}$ & $\begin{array}{l}\text { Comparative LCA on two } \\
\text { batteries type: LFP and LMO }\end{array}$ & $\begin{array}{l}\text { China, Germany, } \\
\text { France, Portugal }\end{array}$ & 2019 [18] \\
\hline & $200,000 \mathrm{~km}$ & $\begin{array}{l}\mathrm{CO}_{2} \text { emissions comparison } \\
\text { between BEVs and ICEVs }\end{array}$ & $\begin{array}{l}\text { United States, } \\
\text { European Union, } \\
\text { Japan, China, } \\
\text { Australia }\end{array}$ & $2019[50]$ \\
\hline & 4000 days & Second life scenarios LCA & Spain & 2019 [2] \\
\hline Gate-to-gate & $1 \mathrm{~km}$ & $\begin{array}{l}\text { Impact of different vehicle } \\
\text { technologies on online } \\
\text { shopping using LCA }\end{array}$ & Thailand & 2018 [51] \\
\hline \multirow{13}{*}{ Well-to-wheel } & - & $\begin{array}{l}\text { LCA study on different size } \\
\text { segments EVs }\end{array}$ & European Union & 2016 [52] \\
\hline & - & Environmental profile for EV & Germany & $2011[53]$ \\
\hline & \multirow[t]{3}{*}{$1 \mathrm{~kg}$ of battery } & $\begin{array}{l}\text { Exergetic efficiency analysis } \\
\text { on thermal management } \\
\text { system for EV an ICEV }\end{array}$ & European Union & 2014 [54] \\
\hline & & LCA on ICEV and BEV & - & 2011 [55] \\
\hline & & $\begin{array}{c}\text { ICEVs and BEVs } \\
\text { environmental comparison } \\
\text { using LCA }\end{array}$ & Switzerland & $2010[56]$ \\
\hline & \multirow[t]{2}{*}{$1 \mathrm{~km}$} & $\begin{array}{l}\text { LCA comparison between EVs } \\
\text { and ICEVs }\end{array}$ & European Union & 2013 [57] \\
\hline & & $\begin{array}{l}\text { Evaluation of GHGs emission } \\
\text { for PHEV }\end{array}$ & United States & 2008 [58] \\
\hline & $10 \mathrm{kWh}$ & $\begin{array}{l}\text { LCA on LFP batteries in PHEV } \\
\text { application }\end{array}$ & European Union & 2010 [59] \\
\hline & $180,000 \mathrm{~km}$ & $\begin{array}{l}\text { LCA on electric, hybrid and } \\
\text { fuel cell vehicles }\end{array}$ & European Union & $2006[60]$ \\
\hline & 180,000 miles & $\begin{array}{c}\text { Energy inputs and GHGs } \\
\text { emission for ICEVs, HEVs and } \\
\text { BEVs }\end{array}$ & $\begin{array}{l}\text { United States } \\
\text { (California) }\end{array}$ & $2012[61]$ \\
\hline & $200,000 \mathrm{~km}$ & $\begin{array}{l}\text { LCA on automotive and } \\
\text { second life for LIBs and } \\
\text { sensitivity on energy mixes. }\end{array}$ & $\begin{array}{l}\text { Portugal, France } \\
\text { and Poland }\end{array}$ & 2014 [9] \\
\hline & $230,500 \mathrm{~km}$ & $\begin{array}{c}\text { Environmental impact of } \\
\text { conventional and electric } \\
\text { vehicles. }\end{array}$ & - & $2011[62]$ \\
\hline & $\begin{array}{l}50 \mathrm{MJ} \text { (equivalent to } \\
100 \mathrm{~km} \text { ) }\end{array}$ & $\begin{array}{c}\text { Environmental comparison } \\
\text { between LIBs and NMHs in } \\
\text { EV applications. }\end{array}$ & European Union & $2011[63]$ \\
\hline
\end{tabular}


Table 1. Cont.

\begin{tabular}{|c|c|c|c|c|}
\hline LCA ${ }^{\text {a }}$ Approach & Functional Unit (F.U.) & Main Topic & Location & References \\
\hline \multicolumn{5}{|c|}{ Others } \\
\hline \multirow{4}{*}{ Cradle-to-grave } & $\mathrm{kg}$ of batteries & $\begin{array}{l}\text { Material and energy flows for } \\
\text { different LIB chemistries. }\end{array}$ & United States & 2014 [64] \\
\hline & $20 \mathrm{kWh}$ & $\begin{array}{l}\text { Material and energy flow for } \\
\text { NMC production }\end{array}$ & - & 2013 [65] \\
\hline & - & Energy and mass flow & European Union & $2007[66]$ \\
\hline & - & Cost analysis for LIBs & United States & $2000[67]$ \\
\hline
\end{tabular}

${ }^{a}$ life cycle assessment; ${ }^{b}$ lithium ion batteries; ${ }^{\mathrm{c}}$ greenhouse gases; ${ }^{\mathrm{d}}$ greenhouse gases, regulated emissions, and energy use in transportation; ${ }^{\mathrm{e}}$ nickel manganese cobalt lithium ion battery; ${ }^{\mathrm{f}}$ energy storage system; ${ }^{\mathrm{g}}$ economic input-output; ${ }^{\mathrm{h}}$ electric vehicle; ${ }^{\mathrm{i}}$ internal combustion engine vehicles; ${ }^{\mathrm{j}}$ battery electric vehicles; ${ }^{\mathrm{k}}$ lithium manganese oxide lithium ion battery; ${ }^{1}$ plug-in hybrid electric vehicle.

Seventeen percent of the studies considered a cradle-to-gate approach. For example, Liang et al. [23] focused on the evaluation of emissions related to the production of batteries. Seven percent followed different approaches such as gate-to-gate, cradle-to-cradle and end-of-life.

Figure 5 shows the percentage distribution of the impact categories of all the studies considered in this review.

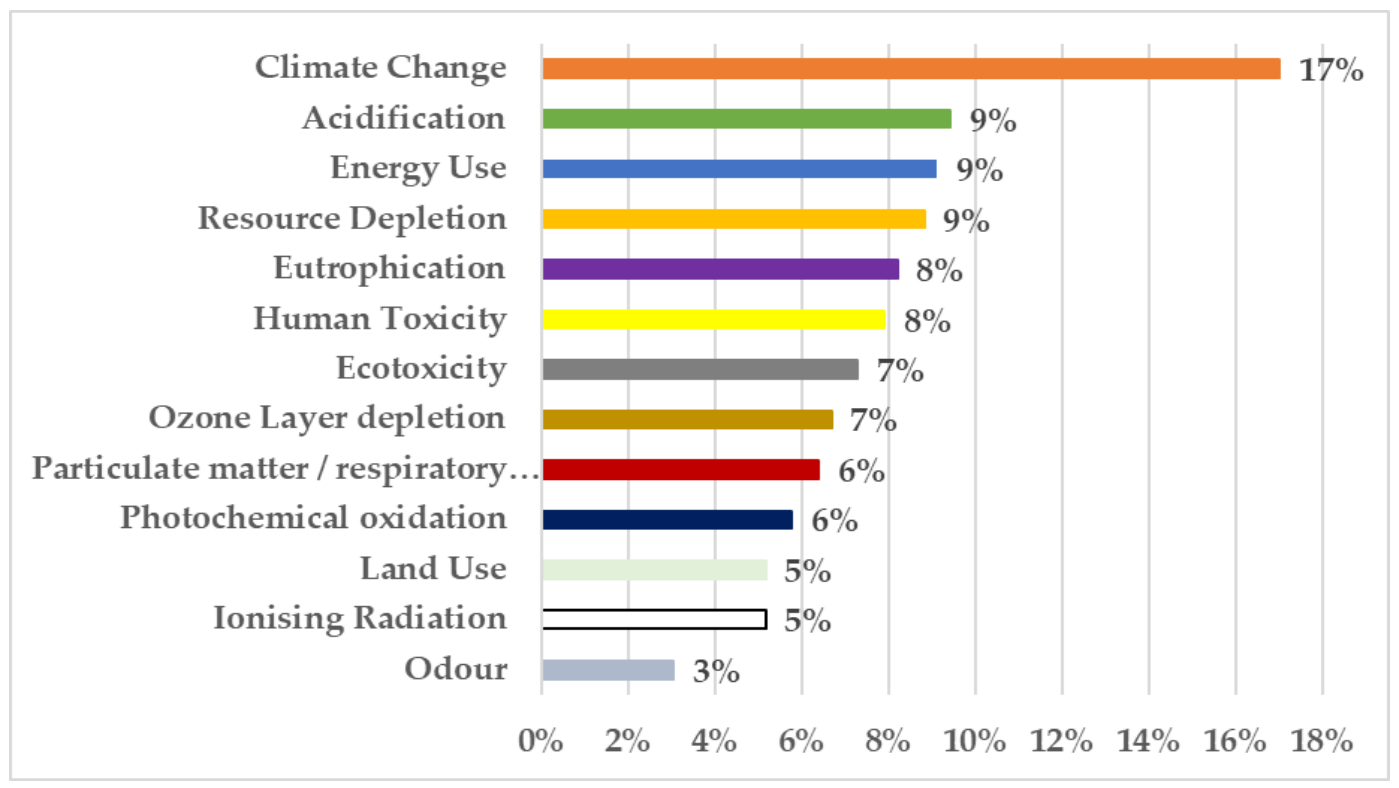

Figure 5. Impact category distribution among the reviewed studies.

Climate change and energy use are the most common impact categories. They are useful to evaluate technical and environmental performances of products and processes. The climate change category is related to greenhouse gas emissions (GHGs), while energy use gives an indication of the harvested energy across the life cycle of the considered process. There is a strong relevance between climate change and energy use; thus, it is possible to speculate that energy intensive processes are more impacting from a climate change perspective [21] and the magnitude of this correlation is related to the energy mix selected to perform the study. The more the energy mix relates to non-renewable sources and the higher is supposed to be the magnitude of the climate change category.

\section{LCA Application to Lithium Ion Batteries for Automotive: A Practical Point of View}

The widespread use of lithium-ion battery's systems in electronics and vehicles has pushed towards the assessment of their environmental impacts [20]. LCA studies on LIBs appeared in the early 2000s and their number increased over time. Among the considered studies, $38 \%$ are related to 
LCA studies on lithium ion battery, while $55 \%$ are related to life cycle assessments on electric vehicle powered by a lithium ion battery pack.

The geographic location in which the LCA studies were performed is one of the aspects taken into consideration. Figure 6 shows that more than half (57\%) of the studies have been conducted in Europe considering an average European energy mix, 21\% of the studies have been conducted in the USA considering an average USA energy mix, while about $6 \%$ have used a Chinese energy mix. Other contributions come from Canada, Brazil, Japan and Australia.

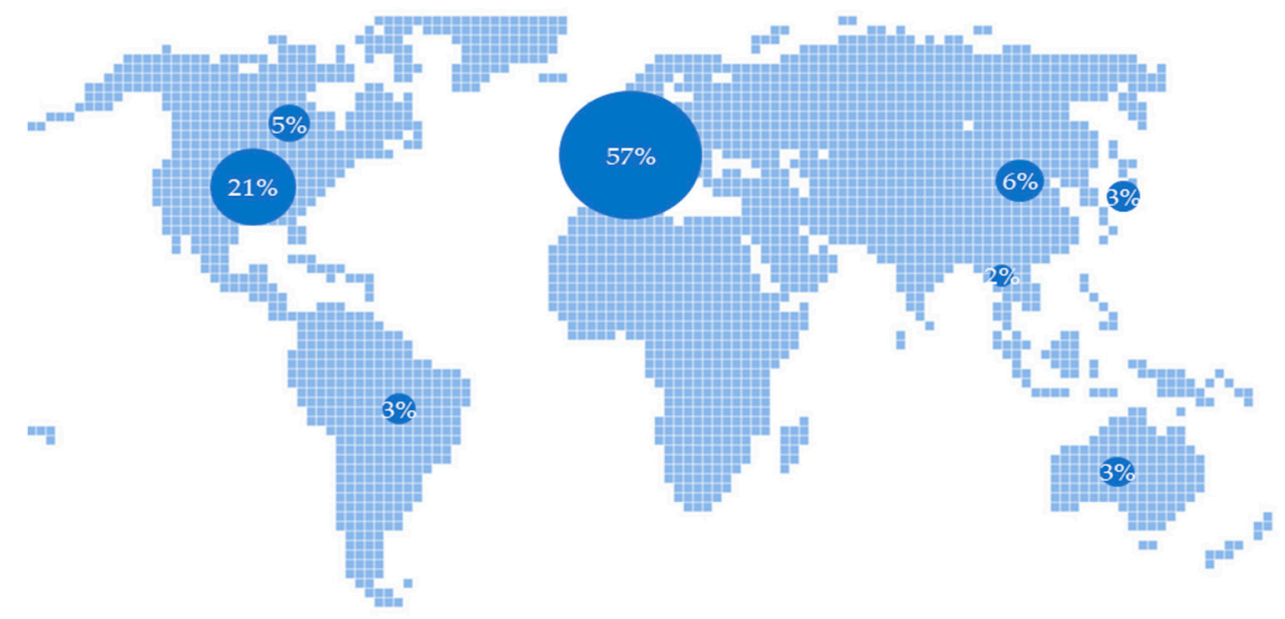

Figure 6. Geographic location considered in the LCA studies.

A second important aspect taken into consideration concerns the cathode's chemistry of the lithium ion batteries. In $6 \%$ of the papers, the chemistry of the battery is not specified. The range of chemistry considered in the papers is shown in Figure 7.

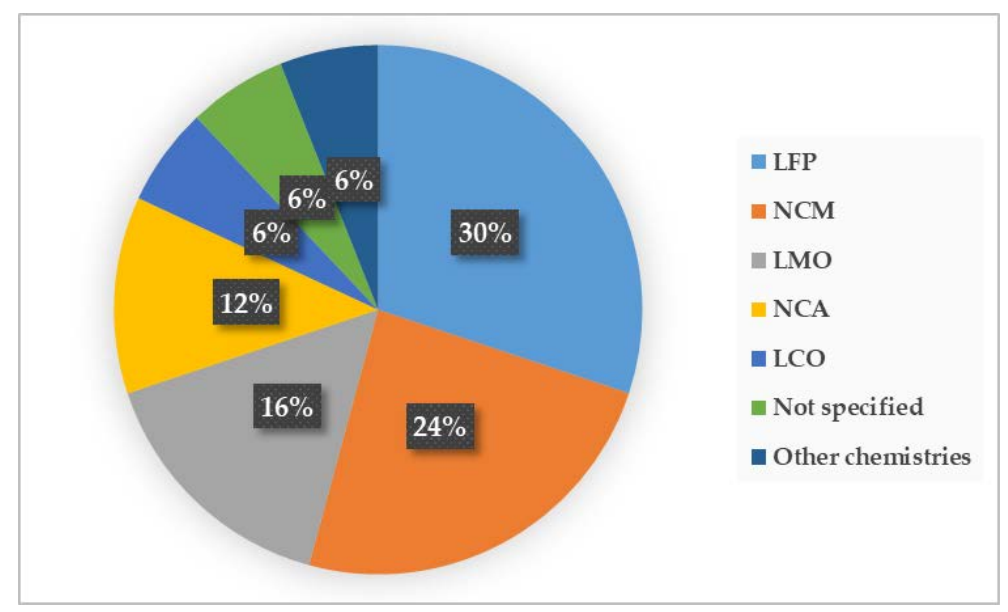

Figure 7. The considered LIBs' chemistries and their respective shares; LFP (lithium iron phosphate); NCM (lithium nickel cobalt manganese); LMO (lithium manganese oxide); LCO (lithium cobalt oxide); NCA (lithium nickel cobalt aluminum); LCP (lithium cobalt phosphate); LFMP (lithium iron manganese phosphate); LMP (lithium metal polymer); LCN (lithium cobalt nickel).

Lithium iron phosphate (LFP) and nickel cobalt manganese (NCM) are the most analyzed chemistries. LFP batteries are made of cheap, nontoxic and easily accessible materials like iron and phosphorus [20]. The cobalt-based batteries show high environmental impacts to human and ecosystems because of the metal extraction process [68]. Furthermore, LFP batteries are safer than cobalt-based batteries [69]. For these reasons, LFPs are the best candidates to be used for next generation 
of green LIBs. NCM is the most diffuse cathode's chemistry in the EVs sold in Europe, Japan and the United States [15].

In the analyzed works, it is possible to evaluate the average ratio between the weight of a LIB and its capacity. From Figure 8, it is possible to assess an average value of the ratio capacity/weight [kWh/kg] equal to 0.1103 . The inverse value is equal to $9.066 \mathrm{~kg} / \mathrm{kWh}$ and gives an indication of the average energy density. The batteries with NCM and LMO cathodes' chemistries have values of the weight/capacity ratio lower than the average. Other chemistries, such as LFP, have values higher than the average, due to the different energy densities among the different chemistries. From a size point of view, batteries with a lower value of weight/capacity are preferable for automotive applications. Obviously, lighter batteries are less impacting on the consumption of electricity.

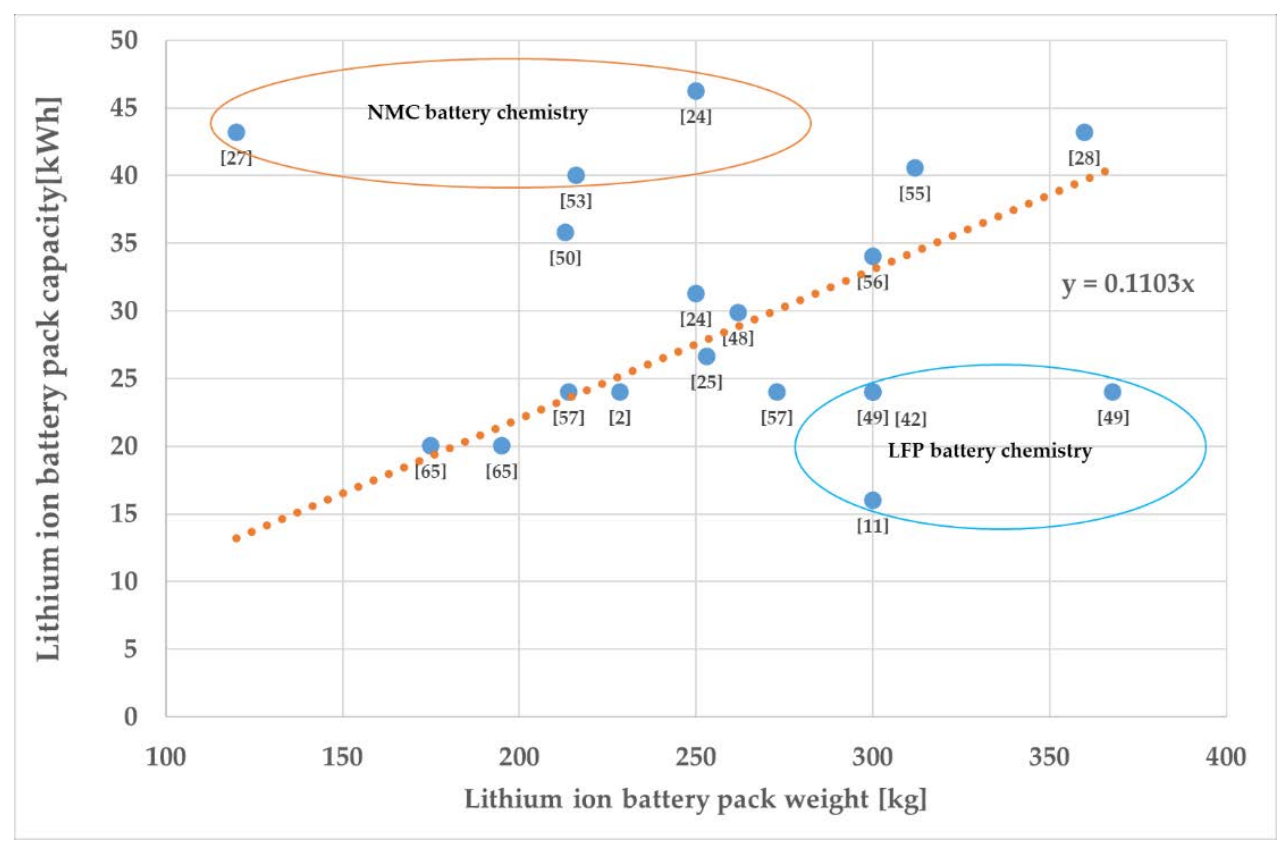

Figure 8. The trend of the ratio between lithium ion battery pack weight and lithium ion battery pack capacity.

\section{LCA Application to Lithium Ion Batteries for Automotive: A Methodological Point of View}

In this section, the reviewed studies are presented from a methodological point of view. The approaches adopted in the LCA main phases (goal and scope definition, inventory analysis, life cycle impact assessment, interpretation) are going to be underlined.

\subsection{Goal and Scope Definition}

In the goal and scope definition's section, F.U. and system boundaries are defined. Furthermore, all the assumptions are stated and discussed.

The most common F.U. ( $33.90 \%$ of the studies) is the distance traveled by the vehicles. It is a common choice when comparing the environmental behavior of different vehicles (i.e., internal combustion engine vehicle and electric vehicle) [44]. The second most common F.U. (30.51\%) is the energy provided by the batteries. It is a correct choice when it is necessary to consider the influence of parameters such as lifetime, efficiency and depth of discharge (DOD) on the output delivered by the batteries [33]. The third most common F.U. (16.95\%) is the battery pack mass. This type of F.U. is commonly used when it is necessary to compare different cathode materials [20] or when the work mainly relies on LIBs' production phases focusing on raw materials' acquisition, transportation, production [21] and EOL recycling phases. 
There are other possibilities for choosing a F.U. to perform an LCA study. Ioakimidis et al. [2], for example, have chosen an amount of time (4000 days) as F.U. In their work, they considered a second life repurposing for batteries as energy storage units in building. They were able to compare two scenarios (base case and repurposing scenario) on a time basis [2]. All the F.U. definitions are valid because the choice depends on what is the focus of the analysis.

\subsection{Inventory Analysis}

The inventory analysis' phase (LCI) is one of the most crucial in performing an LCA study. The study performed must afford the problems of data quality and their availability. The primary data, collected from stakeholder of lithium ion batteries' supply chain, can be subject to non-disclosure agreements and cannot be easily accessed. The recycling of lithium ion batteries is a novel problem and it is likely to experience lack of data. Another way to obtain primary data is to perform experimental procedures. Databases on which LCA software tools are built can be considered as a sort of benchmark for data. These are the so-called secondary data. It would be preferable to perform LCA studies using inventories totally made up of primary data, because they are more reliable since their operational origin. Secondary data represent a valid substitute if they are based on robust models and assumptions.

Among the reviewed papers, $83 \%$ used a mix of primary and secondary data, $12 \%$ used only primary data and, finally, $5 \%$ only secondary data.

The most cited articles are Majeau-Bettez et al. [63] (in 19\% of the papers), Hischier et al. [66] (in 13\% of the papers) and Zackrisson et al. [59] (in 10\% of the papers).

Around $41 \%$ of the reviewed papers (i.e., 24) do not precisely state which database is used to perform the LCI phase. Among the remaining studies, Ecoinvent is chosen in $66 \%$ of the studies, while BatPac is preferred in $17 \%$ of the studies. Ecoinvent is developed by the Swiss Centre for Life Cycle Inventories. It contains around 17,000 LCI datasets in many areas such as energy supply, agriculture, transport, biofuels and biomaterials, bulk and specialty chemicals, construction materials, wood, and waste treatment [70].

Finally, another important aspect that can be pointed out is related to the software tool used to perform the LCA. In $49 \%$ of the reviewed studies, it is not specified. In these cases, it would be useful to know if the authors have chosen not to use any software, and in this case why and what calculations were made. Among the remaining 51\% studies, SimaPro is used in $38 \%$ of the cases, GREET in $31 \%$ GaBi in $25 \%$ and OpenLCA in $6 \%$.

\subsection{Life Cycle Impact Assessment}

In the life cycle impact assessment's phase (LCIA), the potential environmental impacts are calculated in relation to the LCI phase results.

In $23 \%$ of the reviewed papers, it is not clearly expressed which LCIA method is used. Besides these studies, the most used LCIA method is ReCiPe (19\%) developed by PRè Sustainability in collaboration with Dutch National Institute for Public Health and the Environment (RIVM), Radboud University Nijmegen and Norwegian University of Science and Technology [71]. The ReCiPe method is able to determine environmental impacts category on two levels: midpoint and endpoint. Midpoint indicators focus on an environmental problem while endpoint indicators show the impact from a higher aggregation level. The passage from midpoint to endpoint simplifies the LCIA phase, although the uncertainty could increase due to the aggregation process. Other LCIA methods used are IPCC $(9 \%)$ and CML-IA (9\%).

Among the reviewed studies, 22.8\% consider only one impact category (i.e., global warming, potential or cumulative energy demand, CED, etc.). The remaining $77.2 \%$ consider more than one impact category.

Where possible, data were derived from the studies considered for the critical review. Some results in terms of impact categories per $\mathrm{kg}$ of LIBs are shown in Figure 9. The process of data obtained from the reviewed papers was not straightforward and the values gained show a lot of variability. 
This variability can be related to the different system boundaries among the different studies and to the lack of precise numerical data.

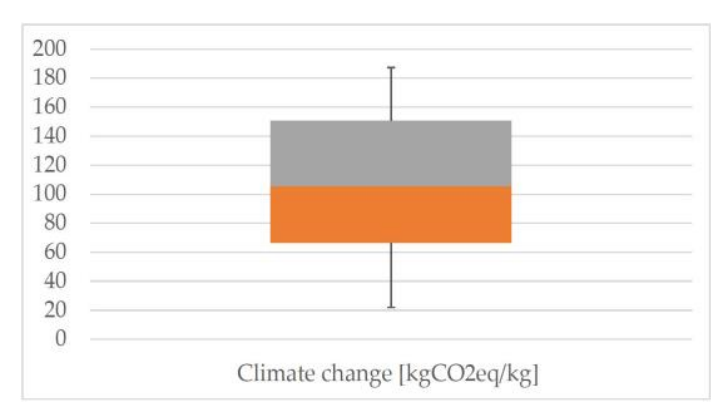

(a)

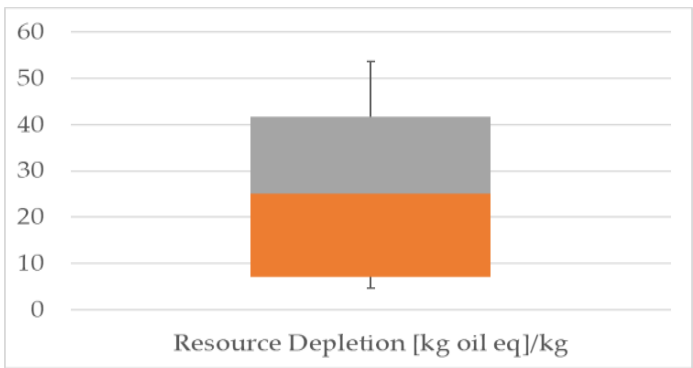

(c)

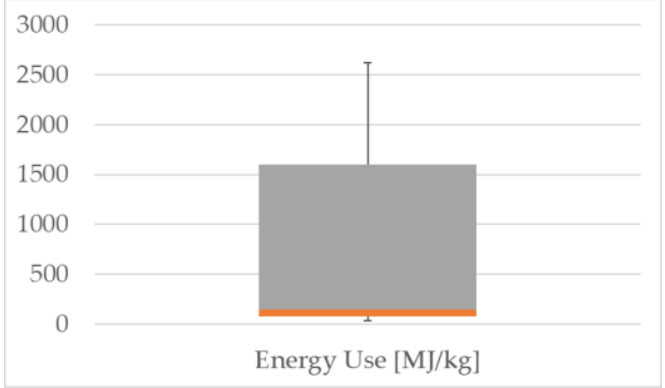

(b)

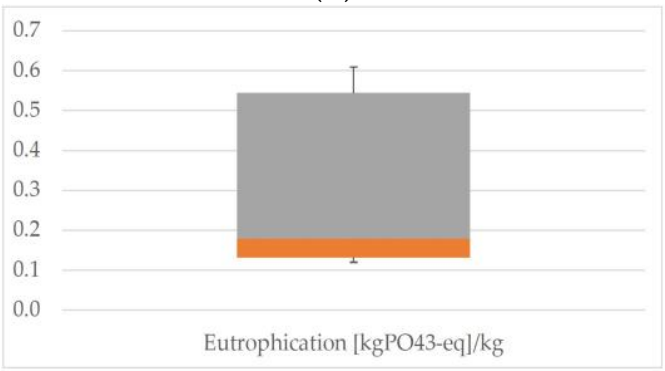

(d)

Figure 9. (a) Climate change value, derived from papers, per kg of batteries; (b) Energy use, derived from papers, per kg of batteries; (c) resource depletion, derived from papers, per kg of batteries; (d) Eutrophication, derived from papers, per $\mathrm{kg}$ of batteries.

\subsection{Interpretation}

Interpretation is the last phase of an LCA study. Usually it includes a sensitivity analysis and a discussion on the reliability of results. Many reviewed papers have not provided numerical values of the environmental impacts and this complicates the comparison of results. When hypotheses are made, it is important to check the influence of the input parameters on the obtained results. In order to quantify this influence, a sensitivity analysis has to be conducted. As a matter of fact, in $51 \%$ of the reviewed studies a sensitivity analysis has been performed.

\section{Conclusions}

This review aims to give critical insights into the upcoming changes in the application of LCA method to lithium ion batteries in the automotive sector.

More than half of the studies are conducted in Europe and considered an average European energy mix. The problem of assessing the environmental impacts of batteries is less acute in countries where batteries are manufactured. Other studies are necessary to quantify the LIB's environmental impacts in countries in which battery production takes place. An increase of LCA studies on LIBs' environmental impacts is necessary considering the trends of production and use of these devices in the next ten years. The environmental impacts need to be precisely quantified in order to increase the sustainability of the electric mobility.

Lithium iron phosphate (LFP) and nickel cobalt manganese (NCM) are the most analyzed chemistries for electric batteries, but different chemistries will be analyzed in the future as long as they become more widespread. In fact, as emerged from the analysis, batteries with a lower value of weight/capacity are preferable for automotive applications, whereas lighter batteries are less impacting on vehicle's electricity consumption. New chemistries are necessary to meet these requirements. The cradle-to-grave approach is adopted in around $50 \%$ of the case studies, while climate change and energy use are the most used impact categories. The results obtained by the studies considered 
in the review emphasized the potential of EVs and LIBs to reduce the overall contribution of the transportation sector to GHG emissions.

From a methodological point of view, the followings are the main outcomes of the review. In the goal and scope definition, the distance traveled by the vehicles is the most used F.U. because the studies focus mainly on comparing the different vehicles. In the inventory analysis, Ecoinvent is the preferred database, while SimaPro is the preferred software tool. The lack of primary data is a crucial concern. It is likely that the more the EVs become widespread, the more data will be accessible. In the life cycle impact assessment, ReCiPe is the most used method. In the interpretation, many articles do not provide all the numerical values, thus not allowing an easy comparison of the environmental results.

It is suggested that any further LCA study on LIBs from automotive application should adopt a cradle-to-grave approach at least. These LCA studies should rely more on recent primary data to be the more accurate as possible.

Author Contributions: All authors contributed equally to this paper. All authors have read and agreed to the published version of the manuscript.

Funding: This research received no external funding.

Acknowledgments: This article was produced as part of Ph.D. research project about "Batteries for electric mobility: Life Cycle Assessment and recycling processes".

Conflicts of Interest: The authors declare no conflict of interest.

\section{Abbreviations:}

\begin{tabular}{ll} 
BEV & Battery Electric Vehicle \\
CED & Cumulative Energy Demand \\
DOD & Depth Of Discharge \\
EIO & Economic Input-Output \\
EOL & End Of Life \\
ESS & Energy Storage System \\
EV & Electric Vehicle \\
F.U. & Functional Unit \\
GHG & Greenhouse Gas \\
HEV & Hybrid Electric Vehicle \\
ICEV & Internal Combustion Engine Vehicle \\
IF & Impact Factor \\
IPCC & Intergovernmental Panel on Climate Change \\
ISO & International Standards Organization \\
LCA & Life Cycle Assessment \\
LCI & Life Cycle Inventory \\
LCIA & Life Cycle Impact Assessment \\
LCN & Lithium Cobalt Nickel Battery \\
LCO & Lithium Cobalt Oxide Lithium Ion Battery \\
LCP & Lithium Cobalt Phosphate Battery \\
LFMP & Lithium Iron Manganese Phosphate \\
LFP & Lithium Iron Phosphate Lithium Ion Battery \\
LIB & Lithium Ion Battery \\
LMO & Lithium Manganese Oxide Lithium Ion Battery \\
LMP & Lithium Metal Polymer Battery \\
NCA & Lithium Nickel Cobalt Aluminum Battery \\
NMC & Nickel Manganese Cobalt Lithium Ion Battery \\
NMH & Nickel-Metal Hydride \\
PHEV & Plug-in Hybrid Electric Vehicle \\
SOH & State Of Health \\
SSB & Solid State Battery \\
\hline &
\end{tabular}




\section{References}

1. Hausbrand, R.; Cherkashinin, G.; Ehrenberg, H.; Gröting, M.; Albe, K.; Hess, C.; Jaegermann, W. Fundamental degradation mechanisms of layered oxide Li-ion battery cathode materials: Methodology, insights and novel approaches. Mater. Sci. Eng. B 2015, 192, 3-25. [CrossRef]

2. Ioakimidis, C.S.; Murillo-Marrodán, A.; Bagheri, A.; Thomas, D.; Genikomsakis, K.N. Life Cycle Assessment of a Lithium Iron Phosphate (LFP) Electric Vehicle Battery in Second Life Application Scenarios. Sustainability 2019, 11, 2527. [CrossRef]

3. Raugei, M.; Winfield, P. Prospective LCA of the production and EoL recycling of a novel type of Li-ion battery for electric vehicles. J. Clean. Prod. 2018, 213, 926-932. [CrossRef]

4. Lin, C.; Tang, A.; Mu, H.; Wang, W.; Wang, C. Aging Mechanisms of Electrode Materials in Lithium-Ion Batteries for Electric Vehicles. J. Chem. 2015, 2015, 104673. [CrossRef]

5. Mayyas, A.; Steward, D.; Mann, M. The case for recycling: Overview and challenges in the material supply chain for automotive li-ion batteries. Sustain. Mater. Technol. 2019, 19, e00087. [CrossRef]

6. Curry, C. Lithium-ion battery costs and market. Bloom New Energy Finance 2017, 5, 1-12.

7. Hassan, M.F.; Guo, Z.; Chen, Z.; Liu, H.-K. $\alpha-\mathrm{Fe}_{2} \mathrm{O}_{3}$ as an anode material with capacity rise and high rate capability for lithium-ion batteries. Mater. Res. Bull. 2011, 46, 858-864. [CrossRef]

8. Waag, W.; Käbitz, S.; Sauer, D.U. Experimental investigation of the lithium-ion battery impedance characteristic at various conditions and aging states and its influence on the application. Appl. Energy 2013, 102, 885-897. [CrossRef]

9. Faria, R.; Marques, P.; Garcia, R.; Moura, P.; Freire, F.; Delgado, J.; de Almeida, A. Primary and secondary use of electric mobility batteries from a life cycle perspective. J. Power Sources 2014, 262, 169-177. [CrossRef]

10. Ahmadi, L.; Yip, A.; Fowler, M.; Young, S.B.; Fraser, R.A. Environmental feasibility of re-use of electric vehicle batteries. Sustain. Energy Technol. Assess. 2014, 6, 64-74. [CrossRef]

11. Ahmadi, L.; Young, S.; Fowler, M.; Fraser, R.; Ahmadi achachlouei, M. A cascaded life cycle: Reuse of electric vehicle lithium-ion battery packs in energy storage systems. Int. J. Life Cycle Assess. 2015. [CrossRef]

12. Bobba, S.; Mathieux, F.; Ardente, F.; Blengini, G.A.; Cusenza, M.A.; Podias, A.; Pfrang, A. Life Cycle Assessment of repurposed electric vehicle batteries: An adapted method based on modelling energy flows. J. Energy Storage 2018, 19, 213-225. [CrossRef]

13. Grandjean, T.R.B.; Groenewald, J.; McGordon, A.; Widanage, W.D.; Marco, J. Accelerated Internal Resistance Measurements of Lithium-Ion Cells to Support Future End-of-Life Strategies for Electric Vehicles. Batteries 2018, 4, 49. [CrossRef]

14. Boyden, A.; Soo, V.K.; Doolan, M. The Environmental Impacts of Recycling Portable Lithium-Ion Batteries. Procedia CIRP 2016, 48, 188-193. [CrossRef]

15. Dai, Q.; Kelly, J.C.; Gaines, L.; Wang, M. Life Cycle Analysis of Lithium-Ion Batteries for Automotive Applications. Batteries 2019, 5, 48. [CrossRef]

16. International Standard Organization. ISO 14040: Environmental Management-Life Cycle Assessment-Principles and Framework; International Standard Organization: Geneva, Switzerland, 1997.

17. International Standard Organization. ISO 14044: Environmental Management-Life Cycle Assessment_Requirements and Guidelines; International Standard Organization: Geneva, Switzerland, 1997.

18. Marques, P.; Garcia, R.; Kulay, L.; Freire, F. Comparative life cycle assessment of lithium-ion batteries for electric vehicles addressing capacity fade. J. Clean. Prod. 2019, 229, 787-794. [CrossRef]

19. Unterreiner, L.; Jülch, V.; Reith, S. Recycling of Battery Technologies-Ecological Impact Analysis Using Life Cycle Assessment (LCA). Energy Procedia 2016, 99, 229-234. [CrossRef]

20. Wang, L.; Wu, H.; Hu, Y.; Yu, Y.; Huang, K. Environmental Sustainability Assessment of Typical Cathode Materials of Lithium-Ion Battery Based on Three LCA Approaches. Processes 2019, 7, 83. [CrossRef]

21. Yin, R.; Hu, S.; Yang, Y. Life cycle inventories of the commonly used materials for lithium-ion batteries in China. J. Clean. Prod. 2019, 227, 960-971. [CrossRef]

22. Mcmanus, M. Environmental consequences of the use of batteries in low carbon systems: The impact of battery production. Appl. Energy 2012, 93. [CrossRef]

23. Liang, Y.; Su, J.; Xi, B.; Yu, Y.; Ji, D.; Sun, Y.; Cui, C.; Zhu, J. Life cycle assessment of lithium-ion batteries for greenhouse gas emissions. Resour. Conserv. Recycl. 2016, 117, 285-293. [CrossRef] 
24. Elzein, H.; Dandres, T.; Levasseur, A.; Samson, R. How can an optimized life cycle assessment method help evaluate the use phase of energy storage systems? J. Clean. Prod. 2019, 209, 1624-1636. [CrossRef]

25. Zhao, S.; You, F. Comparative Life-Cycle Assessment of Li-Ion Batteries through Process-Based and Integrated Hybrid Approaches. ACS Sustain. Chem. Eng. 2019, 7. [CrossRef]

26. Ellingsen, L.A.-W.; Majeau-Bettez, G.; Singh, B.; Srivastava, A.K.; Valøen, L.O.; Strømman, A.H. Life Cycle Assessment of a Lithium-Ion Battery Vehicle Pack. J. Ind. Ecol. 2014, 18, 113-124. [CrossRef]

27. Cerdas, F.; Andrew, S.; Thiede, S.; Herrmann, C. Environmental Aspects of the Recycling of Lithium-Ion Traction Batteries. In Recycling of Lithium-Ion Batteries: The LithoRec Way; Kwade, A., Diekmann, J., Eds.; Sustainable Production, Life Cycle Engineering and Management; Springer International Publishing: Cham, Germany, 2018; pp. 267-288. ISBN 978-3-319-70572-9.

28. Li, B.; Gao, X.; Li, J.; Yuan, C. Life Cycle Environmental Impact of High-Capacity Lithium Ion Battery with Silicon Nanowires Anode for Electric Vehicles. Environ. Sci. Technol. 2014, 48, 3047-3055. [CrossRef]

29. Troy, S.; Schreiber, A.; Reppert, T.; Gehrke, H.-G.; Finsterbusch, M.; Uhlenbruck, S.; Stenzel, P. Life Cycle Assessment and resource analysis of all-solid-state batteries. Appl. Energy 2016, 169, 757-767. [CrossRef]

30. Hammond, G.P.; Hazeldine, T. Indicative energy technology assessment of advanced rechargeable batteries. Appl. Energy 2015, 138, 559-571. [CrossRef]

31. Kushnir, D.; Sandén, B. Multi-level energy analysis of emerging technologies: A case study in new materials for lithium ion batteries. J. Clean. Prod. 2011, 19, 1405-1416. [CrossRef]

32. Ishihara, K.; Kihira, N.; Terada, N.; Iwahori, T. Environmental Burdens of Large Lithium-ion Batteries Developed in a Japanese National Project; Central Research Institute of Electric Power Industry: Tokyo, Japan, 2013; pp. 1-5.

33. Vandepaer, L.; Cloutier, J.; Amor, B. Environmental impacts of Lithium Metal Polymer and Lithium-ion stationary batteries. Renew. Sustain. Energy Rev. 2017, 78, 46-60. [CrossRef]

34. Rydh, C.J.; Sandén, B.A. Energy analysis of batteries in photovoltaic systems. Part I: Performance and energy requirements. Energy Convers. Manag. 2005, 46, 1957-1979. [CrossRef]

35. Gerssen-Gondelach, S. Performance of batteries for electric vehicles on short and longer term. J. Power Sources 2012, 212, 111-129. [CrossRef]

36. Zackrisson, M. Life cycle assessment of long life lithiumelectrode for electric vehicle batteries: 5Ah cell. Eng. Technol. 2016, 1-34.

37. Qiao, Q.; Zhao, F.; Liu, Z.; Jiang, S.; Hao, H. Cradle-to-gate greenhouse gas emissions of battery electric and internal combustion engine vehicles in China. Appl. Energy 2017, 204, 1399-1411. [CrossRef]

38. Egede, P.; Dettmer, T.; Herrmann, C.; Kara, S. Life Cycle Assessment of Electric Vehicles-A Framework to Consider Influencing Factors. Procedia CIRP 2015, 29, 233-238. [CrossRef]

39. Pero, F.D.; Delogu, M.; Pierini, M. Life Cycle Assessment in the automotive sector: A comparative case study of Internal Combustion Engine (ICE) and electric car. Procedia Struct. Integr. 2018, 12, 521-537. [CrossRef]

40. Dunn, J.B.; Gaines, L.; Sullivan, J.; Wang, M.Q. Impact of recycling on cradle-to-gate energy consumption and greenhouse gas emissions of automotive lithium-ion batteries. Environ. Sci. Technol. 2012, 46, 12704-12710. [CrossRef] [PubMed]

41. Gaines, L.; Sullivan, J.; Burnham, A. Life-Cycle Analysis for Lithium-Ion Battery Production and Recycling. In Proceedings of the Transportation Research Board 90th Annual Meeting, Washington, DC, USA, 23-27 January 2011; pp. 23-27.

42. Sullivan, J.; Burnham, A.; Wang, M. Energy-consumption and carbon-emission analysis of vehicle and component manufacturing. J. Ind. Ecol. 2010, 17. [CrossRef]

43. Souza, L.; Lora, E.; Palacio, J.; Rocha, M.; Renó, M.; Venturini, O. Comparative environmental life cycle assessment of conventional vehicles with different fuel options, plug-in hybrid and electric vehicles for a sustainable transportation system in Brazil. J. Clean. Prod. 2018, 203. [CrossRef]

44. Tagliaferri, C.; Evangelisti, S.; Acconcia, F.; Domenech, T.; Ekins, P.; Barletta, D.; Lettieri, P. Life cycle assessment of future electric and hybrid vehicles: A cradle-to-grave systems engineering approach. Chem. Eng. Res. Des. 2016, 112, 298-309. [CrossRef]

45. Ambrose, H.; Kendall, A. Effects of battery chemistry and performance on the life cycle greenhouse gas intensity of electric mobility. Transp. Res. Part Transp. Environ. 2016, 47, 182-194. [CrossRef]

46. Hernandez, M.; Messagie, M.; De Gennaro, M.; Van Mierlo, J. Resource depletion in an electric vehicle powertrain using different LCA impact methods. Resour. Conserv. Recycl. 2017, 120. [CrossRef] 
47. Jursova, S.; Burchart-Korol, D.; Pustejovska, P. Carbon Footprint and Water Footprint of Electric Vehicles and Batteries Charging in View of Various Sources of Power Supply in the Czech Republic. Environments 2019, 6, 38. [CrossRef]

48. Lastoskie, C.M.; Dai, Q. Comparative life cycle assessment of laminated and vacuum vapor-deposited thin film solid-state batteries. J. Clean. Prod. 2015, 91, 158-169. [CrossRef]

49. Burchart-Korol, D.; Pustejovska, P.; Blaut, A.; Jursová, S.; Korol, J. Comparative life cycle assessment of current and future electricity generation systems in the Czech Republic and Poland. Int. J. Life Cycle Assess. 2018, 23, 2165-2177. [CrossRef]

50. Kawamoto, R.; Mochizuki, H.; Moriguchi, Y.; Nakano, T.; Motohashi, M.; Sakai, Y.; Inaba, A. Estimation of $\mathrm{CO} 2$ Emissions of Internal Combustion Engine Vehicle and Battery Electric Vehicle Using LCA. Sustainability 2019, 11, 2690. [CrossRef]

51. Koiwanit, J.; Hamontree, C. A Comparative of Life Cycle Assessment of a Conventional Van and a Battery Electric Van for an Online Shopping System in Thailand. IOP Conf. Ser. Earth Environ. Sci. 2018, 150, 012030. [CrossRef]

52. Ellingsen, L.A.-W.; Singh, B.; Strømman, A.H. The size and range effect: Lifecycle greenhouse gas emissions of electric vehicles. Environ. Res. Lett. 2016, 11, 054010. [CrossRef]

53. Held, M. Fraunhofer System Research for E-Mobility (FSEM) Current LCA Results and Need for Further Research-PDF Free Download. Available online: https://docplayer.net/14033601-Fraunhofer-system-researchfor-e-mobility-fsem-current-lca-results-and-need-for-further-research.html (accessed on 10 December 2019).

54. Hamut, H.; Dincer, I.; Naterer, G. An Exergoeconomic Analysis of Hybrid Electric Vehicle Thermal Management Systems. J. Clean. Prod. 2014, 67, 187-196. [CrossRef]

55. Frischknech, R. Life Cycle Assessment of Driving Electric Cars and Scope Dependent LCA Models. Life Cycle Assessment of Electric Cars-PDF Free Download. Available online: https://docplayer.net/130868190-Outline-life-cycle-assessment-of-driving-electric-cars-and-scopedependent-lca-models-life-cycle-assessment-of-electric-cars.html (accessed on 10 December 2019).

56. Notter, D.; Gauch, M.; Widmer, R.; Wäger, P.; Stamp, A.; Zah, R.; Althaus, H.-J. Contribution of Li-Ion Batteries to the Environmental Impact of Electric Vehicles. Environ. Sci. Technol. 2010, 44. [CrossRef]

57. Hawkins, T.; Singh, B.; Majeau-Bettez, G.; Strømman, A. Comparative Environmental Life Cycle Assessment of Conventional and Electric Vehicles. J. Ind. Ecol. 2013, 17. [CrossRef]

58. Samaras, C.; Meisterling, K. Life Cycle Assessment of Greenhouse Gas Emissions from Plug-in Hybrid Vehicles: Implications for Policy. Environ. Sci. Technol. 2008, 42, 3170-3176. [CrossRef] [PubMed]

59. Zackrisson, M.; Avellán, L.; Orlenius, J. Life cycle assessment of lithium-ion batteries for plug-in hybrid electric vehicles-Critical issues. J. Clean. Prod. 2010, 18, 1519-1529. [CrossRef]

60. Van den Bossche, P.; Vergels, F.; Van Mierlo, J.; Matheys, J.; Van Autenboer, W. SUBAT: An assessment of sustainable battery technology. J. Power Sources 2006, 162, 913-919. [CrossRef]

61. Aguirre, K.; Eisenhardt, L.; Lim, C.; Nelson, B.; Norring, A.; Slowik, P.; Tu, N.; Rajagopal, D.D. Lifecycle Analysis Comparison of a Battery Electric Vehicle and a Conventional Gasoline Vehicle. CARB 2012, 33, $1-119$.

62. Van Mierlo, J.; Boureima, F.; Messagie, M.; Sergeant, N.; Govaerts, L.; Denys, T.; Michiels, H.; Vernaillen, S.; Schrooten, L.; Beckx, C. Clean Vehicle Research: lca and Policy Measures «Clever». Final Rep. Proj. Funded Belg. Sci. Policy 2011.

63. Majeau-Bettez, G.; Hawkins, T.; Strømman, A. Life Cycle Environmental Assessment of Lithium-Ion and Nickel Metal Hydride Batteries for Plug-In Hybrid and Battery Electric Vehicles. Environ. Sci. Technol. 2011, 45, 5454. [CrossRef]

64. Dunn, J.B.; Gaines, L.; Kelly, J.C.; James, C.; Gallagher, K.G. The significance of Li-ion batteries in electric vehicle life-cycle energy and emissions and recycling's role in its reduction. Energy Environ. Sci. 2014, 8, 158-168. [CrossRef]

65. Simon, B.; Weil, M. Analysis of materials and energy flows of different lithium ion traction batteries. Rev. Métallurgie 2013, 1, 65-76. [CrossRef]

66. Hischier, R.; Classen, M.; Lehmann, M.; Scharnhorst, W. Life cycle inventories of electric and electronic equipment: Production, use and disposal. Final Rep. Ecoinvent Data 2007, 2, 1-270.

67. Gaines, L.; Cuenca, R. Costs of Lithium-Ion Batteries for Vehicles; Argonne National Laboratory: Lemont, IL, USA, 2000. [CrossRef] 
68. Kallitsis, E.; Korre, A.; Kelsall, G.; Kupfersberger, M.; Nie, Z. Environmental life cycle assessment of the production in China of lithium-ion batteries with nickel-cobalt-manganese cathodes utilising novel electrode chemistries. J. Clean. Prod. 2020, 254, 120067. [CrossRef]

69. Sun, L.; Wei, C.; Guo, D.; Liu, J.; Zhao, Z.; Zheng, Z.; Jin, Y. Comparative Study on Thermal Runaway Characteristics of Lithium Iron Phosphate Battery Modules Under Different Overcharge Conditions. Fire Technol. 2020, 1-20. [CrossRef]

70. Swiss Centre for Life Cycle Inventories. Ecoinvent 2017-Ecoinvent Database v3.6. 2019. Available online: https://www.ecoinvent.org/ (accessed on 26 March 2020).

71. ReCiPe | PRé Sustainability. Available online: https://www.pre-sustainability.com/recipe (accessed on 1 March 2020).

(C) 2020 by the authors. Licensee MDPI, Basel, Switzerland. This article is an open access article distributed under the terms and conditions of the Creative Commons Attribution (CC BY) license (http://creativecommons.org/licenses/by/4.0/). 